\title{
Behavioral Intentions and Cognitive-Affective Effects of Exposure to YouTube Advertisements among College Students
}

\author{
Abd El-Basit Ahmed Hashem Mahmoud* \\ Othman Fekry Abdelbaki**
}

\begin{abstract}
This study attempted to investigate the exposure to YouTube ads among Egyptian college students, their attitudes towards these ads, behavioral intentions to watch them and the effects of this exposure and to examine the relationships among these variables as well. The current study was theoretically guided by the theory of reasoned action (TRA) and cognitive-affective behavioral model (CAB) through a questionnaire administered to a purposive sample of 390 college students, who watch YouTube videos, from Cairo University, Egypt from February to May 2019.

The results showed that $98.7 \%$ of respondents exposed to YouTube ads, and both of their attitudes towards YouTube ads exposure and their intentions to this exposure were moderately positive. The findings also indicated that their attitudes towards exposure to YouTube ads influenced their behavioral intentions to watch these ads, and it also demonstrated that their behavioral intentions to watch these ads had an impact on the exposure to such ads.
\end{abstract}

KEYWORDS: YouTube ads; theory of reasoned action; cognitiveaffective behavior model; attitudes; behavioral intentions, college students.

* PhD. Sohag University, Egypt, Zarqa University, Jordan

** PhD. Cairo University, Egypt 


\section{INTRODUCTION}

YouTube is a website that carries different types of videos such as consumer-generated video clips, actual shows downloaded from TV, ad parodies, and brand-sponsored films (Moriarty, Mitchell \& Wells, 2012), it is a content-based platform and allows users to share their interests and creativity (Voorveld, van Noort, Muntinga \& Bronner, 2018).

It's functionality and ease of use concerning uploading, searching and playing a video, and the proliferation of cheap and simple video editing software are the primary reasons behind the success and proliferation of YouTube (Smith \& Smith, 2011).

It is founded in December 2005 (Moriarty, Mitchell \& Wells, 2012) by three former PayPal friends to upload videos for friends and others, and in 2006, Google bought YouTube for $\$ 1.65$ billion (Thorson \& Duffy, 2012), since its creation, it has grown into the world's dominant video hosting site (Smith \& Smith, 2011), the most popular social media video sharing platform (Arantes, Figueiredo \& Almeida, 2018), and the second-largest search engine after Google (Rashid \& Zeeshan 2018). Thousands of videos are being uploaded to YouTube daily (Koshy \& Manohar, 2018). According to the Statcounter Global Stats website, Egypt had over 18.50 million active YouTube users in 2019.

The advertising on YouTube is continuously growing (Dehghani, Niaki, Ramezani, \& Sali, 2016), and YouTube ads have become one of the leading revenues of website service providers (Arantes, Figueiredo, Almeida, \& Prates, 2018), since YouTube provides huge opportunities for marketers and advertisers (Yang, Huang, Yang \& Yang, 2017), such as the following:

- Placing ads inside the YouTube videos (Koshy \& Manohar, 2018).

- Offering ad-funded video channels (Araújo, Magno, Meira, Almeida, Hartung \& Doneda, 2017), and creating ad auctions to select ads to be exhibited to users (Arantes, Figueiredo \& Almeida, 2018).

- Providing companies and their audience an opportunity to interact with each other (Rashid, \& Zeeshan, 2018). 
Behavioral Intentions and Cognitive-Affective Effects of Exposure to YouTube Advertisements among College Students

- Providing information about markets and consumption, it is supplied with entertainment, informativeness, and customization of the products and services (Dehghani, Niaki, Ramezani, \& Sali, 2016).

With the launch of the 2008 model Corolla, Toyota employed YouTube ads in selling hundreds of thousands of Corollas (O'Toole, 2011). Shimp and Andrews (2013) identified three major characteristics of YouTube advertising:

- Cost-effectiveness: A free upload on YouTube is more effective and less expensive than print and broadcast advertising delivered via direct mail.

- Consumer engagement: YouTube relies on consumer-generated content that helps to ensure viewing the appropriate YouTube ads and thus is more decentralized in terms of production and usage.

- Integration and ability to drive traffic: A good YouTube ad can integrate with and drive traffic to other sites and other brand promotions.

\section{The Theory of Reasoned Action}

The theory of reasoned action (TRA) assumes that the behavior is influenced by behavioral intentions and these intentions can be explained by both attitudes toward the behavior and subjective norms (Fishbein \& Ajzen, 1975). Ajzen (1991) developed the theory of planned behavior (TPB) by adding perceived behavioral control to TRA to be determinant of both the individual's behavioral intentions and actual behavior.

According to TRA, "the proximal cause of the behavior is an intention to behave, which, in turn, is caused by attitudes and subjective norms" (Trafimow \& Finly, 1996, 820), therefore, the main four components of TRA are:

1) Attitude: It is an individual's evaluation or feeling about performing the target behavior (Luarn \& Lin, 2005).

2) Subjective norm: It refers to the perceived social pressure to engage in the behavior (Tarkiainen \& Sundqvist 2005). 
Behavioral Intentions and Cognitive-Affective Effects of Exposure to YouTube Advertisements among College Students

3) Behavioral intention: It was defined as "an individual's subjective probability of performing a particular behavior and is the major determinant of actual usage behavior" (Kuo \& Yen, 2009, 103).

4) Behavior: It means the observable person's acts that are resulted from behavioral attention (Li \& Leckenby, 2004).

\section{A Cognitive-Affective-Behavioral (CAB) Model}

Lavidge and Steiner (1961) proposed a model that disclosed three sequence effects of advertising: Cognition-Affect-Conation. BallRokeach and DeFleur (1976) also proposed that people depend on mass communication information resources, including advertising, to satisfy a person's needs such as understanding the social world and fantasy-escape from problems and tensions. Different communication motives, communication behaviors, and dependencies on this information lead to different effects (Rubin \& Windahl, 1986). These effects can be categorized under three main categories: Cognition (C), Affect (feelings) (A), and behavior (coactive) (B) (Vakratsas \& Ambler, 1999): First, cognition concerns the knowledge in an individual's mind and how that is obtained (Li \& Leckenby, 2004) such as information about the products (e.g., price, quality, country of origin, warranty). Second, affection refers to the audience's emotional responses that are one of the least explored kinds of effects, such as fear, anxiety, and trigger-happiness (Ball-Rokeach \& DeFleur, 1976), Third, behavioral effects of advertising may be represented in individual purchasing and product usage behavior (Vakratsas \& Ambler, 1999).

\section{QUESTIONS, HYPOTHESES AND PROPOSED MODEL}

The following research questions guided this study to examine respondents' YouTube usage, exposure to YouTube ads, attitudes towards these ads, behavioral intentions to watch these ads, and responses to these ads' exposure.

RQ1: To what extent do the respondents watch YouTube videos?

RQ2: To what extent do the respondents watch YouTube ads?

RQ3: What are the respondents' attitudes toward YouTube ads? 
RQ4: What are the respondents' behavioral intentions to watch these ads?

RQ5: What are the cognitive, affective and behavioral effects of their exposure to these ads?

Besides these survey questions and in the light of TRA and the $\mathrm{CAB}$ model, we suggested the following main hypotheses to investigate the connections among the fore-mentioned variables.

According to TRA, behavioral intentions can be explained by attitudes toward the behavior (Fishbein \& Ajzen, 1975). The relationship between attitudes toward online ads and behavioral intentions to watch these ads was explored by considerable amount of scholars (e.g. Izquierdo-Yusta, Olarte-Pascual \& Reinares-Lara, 2015; Lee, Ham \& Kim, 2013; Lee \& Lee, 2011; Martínez-Ruiz, IaIzquierdo-Yusta, Olarte-Pascual \& Reinares-Lara, 2018; Nainggolan, Azzahro \& Handayani, 2018; Sanne \& Wiese, 2018). Lee and Lee (2011) disclosed that attitudes toward watching online video ads relate positively to the intentions to engage these ads. Lee, Ham, and Kim, (2013) also stated that attitudes towards passing along online video ads affect positively the intention to pass along these ads. Izquierdo-Yusta, Olarte-Pascual, and Reinares-Lara, (2015) also indicated that attitudes toward mobile ads influence positively on intentions to watch these ads.

Likewise, Martínez-Ruiz, IaIzquierdo-Yusta, Olarte-Pascual, and Reinares-Lara (2018) demonstrated the positive relationship between the attitudes toward mobile advertising and the intentions to receive it. Nainggolan, Azzahro, and Handayani (2018) also revealed that attitudes positively influence users' intentions to purchase products that have been offered in mobile advertising. Sanne and Wiese (2018) similarly found that user' attitudes towards watching with Facebook advertising have an impact on his/her intention to watch with this advertising. Accordingly, a first research hypothesis is proposed:

H1. The attitudes toward YouTube ads significantly influence behavioral intentions to watch these ads. 
In the light of TRA also, many researchers examined the impact of behavioral intentions on engagement in this behavior (e.g. Sanne \& Wiese, 2018; Tarkiainen \& Sundqvist, 2005; Trumbo \& Kim, 2015; Wu, Lin \& Lin, 2011; Yang, Huang, Yang \&Yang, 2017).

Tarkiainen and Sundqvist (2005) found that intentions to buy organic food are positively associated with buying this food. $\mathrm{Wu}$, Lin, and Lin (2011) also indicated that the intentions to search ads keywords relate positively to the searching behaviors. Likewise, Trumbo and Kim (2015) stated that behavior is positively associated with intention. Yang, Huang, Yang, and Yang (2017) also stated that consumers' purchase intention affects their shopping behavior. Sanne and Wiese (2018) also revealed that intentions to watch Facebook advertising significantly influence on engagement with this advertising. Hence, we hypothesize that:

H2. The behavioral intentions to watch YouTube ads significantly affect on actual engagement with these ads.

According to Vakratsas and Ambler (1999), exposure to marketing communication messages, including advertising, leads to cognitive, affective and behavioral effects, for example, Asghar, Abbasi, and Zafarullah (2015) confirmed that exposure to ads and sales promotion influence on consumer cognitive responses.

A considerable amount of research has examined the relationship between the exposure to online advertising and its effects (e.g., Asghar, Abbasi \& Zafarullah, 2015; Duffett, 2017; Hong, 2014; Martín-Santana \& Beerli-Palacio, 2012; Schivinski \& Dabrowski, 2015; Zenetti, Bijmolt, Leeflang \& Klapper, 2014). Martín-Santana and Beerli-Palacio (2012) disclosed that exposure to online ads relates significantly and positively with the cognitive, affective and behavioral effects of advertising. Zenetti, Bijmolt, Leeflang, and Klapper (2014) also found that exposure to search engine ads has a positive impact on both advertising awareness (cognitive effect) and brand consumption (behavioral effect). Schivinski and Dabrowski (2015) also found that social media brand communications positively affected cognitive responses, and likewise, Duffett (2017) demonstrated that social media promotion, including advertising, has a 
Behavioral Intentions and Cognitive-Affective Effects of Exposure to YouTube Advertisements among College Students

significant impact on cognitive, affective and behavioral attitudes components.

On the other hand, Hong (2014) found that online ads have some negative cognitive, affective and behavioral impacts, and he disclosed a significant difference between button ads and pop-up ads in their cognitive, affective and behavioral influences. Hence, the relationship between exposure to YouTube advertising and the cognitive, affective, and behavioral effects of this exposure will be tested in the current research through the following three hypotheses:

H3. The exposure to YouTube ads has a positive impact on its cognitive effects.

H4.The exposure to YouTube ads has a positive impact on its emotional effects.

H5. The exposure to YouTube ads has a positive impact on its behavioral effects.

Various marketing communications studies have investigated the relationships among the communication effects (e.g., Ahn \& Back, 2017; Agapito, Valle \& Mendes, 2013; Back \& Parks, 2003; Hamidizadeh, Yazdani, Tabriz, \& Latifi, 2012; Hinson, Boateng, Renner \& Kosiba, 2019; Matthes \& Beyer, 2015; Punyatoya, 2019). Back and Parks (2003) found that cognitive brand loyalty influences on emotional brand loyalty, and emotional brand loyalty impacts on behavioral brand loyalty. Hamidizadeh, Yazdani, Tabriz, \& Latifi, (2012) also indicated that affective response has a positive impact on consumer behavior.

Similarly, Agapito, Valle, and Mendes (2013) highlighted the significant relationships between cognitive, affective, and conative images of the destination. Matthes and Beyer (2015) also highlighted that cognitive involvement leads to emotional involvement. Ahn and Back (2017) also disclosed the positive relationship between cognitive, affective, and conative dimensions of consumer engagement with the branding process. Likewise, Hinson, Boateng, Renner, and Kosiba (2019) demonstrated that cognitive, affective and behavioral dimensions of customer engagement are positively correlated, and Punyatoya (2019) also stated that the cognitive trust is 
positively related to affective trust toward an online retailer, and the both of cognitive and affective trust influences the online behavior.

On the other hand, Hamidizadeh, Yazdani, Tabriz, and Latifi (2012) indicated that cognitive response doesn't have a significant impact on the behavioral one. In line with these results, we hypothesize the following three hypotheses:

H6: Cognitive responses to YouTube ads are positively related to affective responses to these ads.

H7: Affective responses to YouTube ads are positively related to behavioral responses to these ads.

H8: Cognitive responses to YouTube ads are positively related to behavioral responses to these ads.

To understand the associations between the variables of the current study, and to explain the research hypotheses, the model was proposed as the following figure (1).

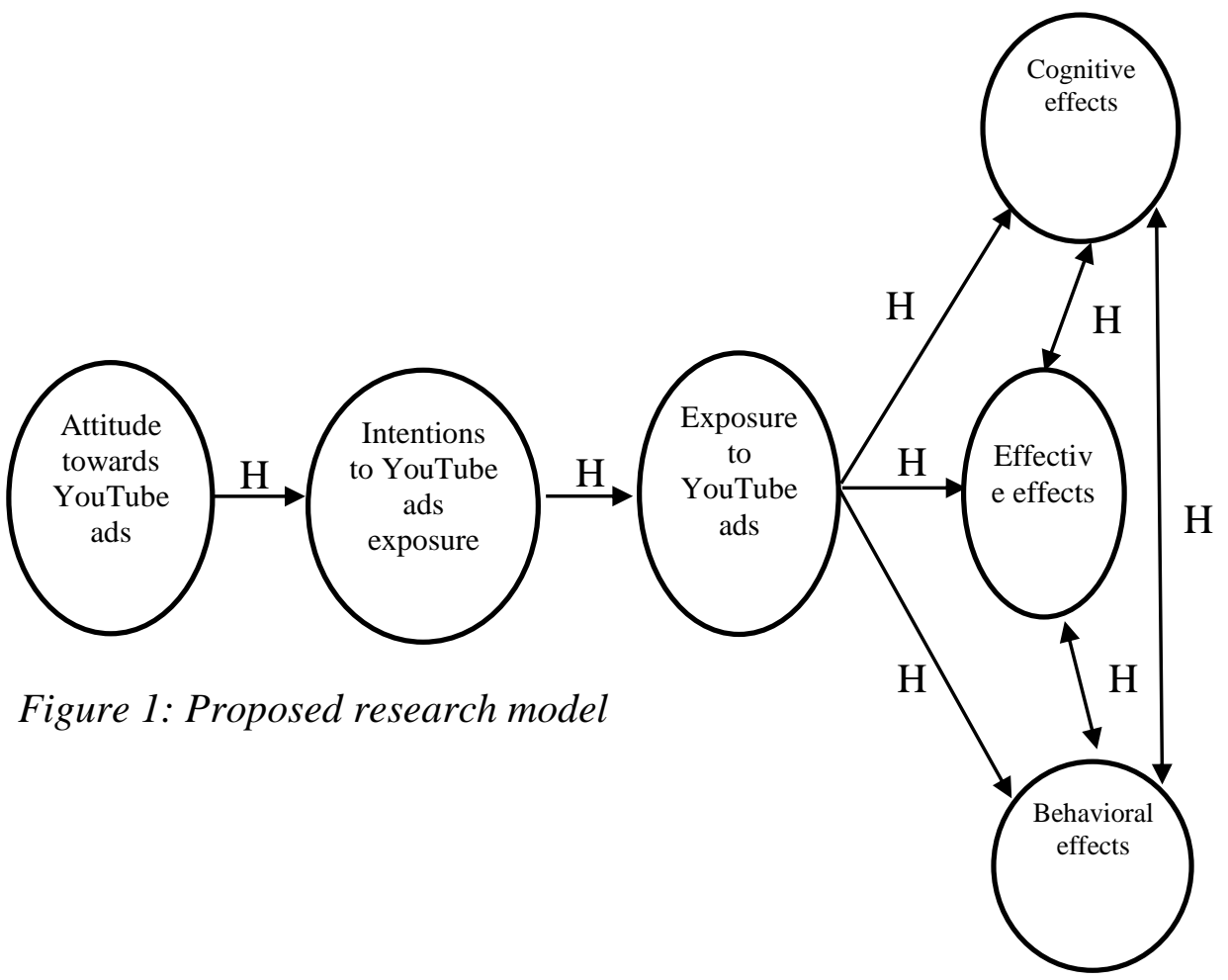

The Scientific Journal of Public Relations \& Advertising Research - Issue 18 - July / December 2019 


\section{RESEARCH METHODOLOGY}

The questionnaire was distributed to a purposive sample of undergraduate students, who use YouTube, from the Faculty of Mass Communication, University of Cairo, Egypt. A total of 390 students responded to the survey from January to March 2019. The questionnaire contained five sections: 1) YouTube use and exposure to YouTube ads, 2) attitudes towards these ads, 3) behavioral intention to engage with the ads, 4) effects of exposure to these ads, and 5) respondents' demographic variables.

\section{Characteristics of the sample}

The sample consisted of 82 males (21\%) and 308 females $(79 \%)$ of the sample. Respondents varied in their sub-disciplines of mass communication, more than half of them reported studying in Radio and TV department $(\mathrm{N}=199,56.21 \%)$, this is followed by Public Relations and Advertising department $(\mathrm{N}=138,35.4 \%)$, and Journalism department $(\mathrm{N}=53,13.6 \%)$ of the sample.

\section{Measures}

\section{1) YouTube Usage}

The time spent on YouTube (usage) amongst students was measured by responses to the question "How many hours do you use YouTube daily?" on a 4-point scale ranging from 1 (less than one hour) to 4 (three hours or more).

\section{2) Exposure to YouTube ads}

To measure respondents' exposure to YouTube ads, the respondents were asked "How often they are exposed to YouTube ads?" and the researchers used two items that included selective and accidental exposure to YouTube ads. Subjects responded to each item with a 5point Likert scale ranging from (1) Never to (4) Often.

\section{3) Attitudes towards YouTube Advertising}

A ten-item with a 5-point Likert-scale ranging from (0) strongly disagree to (4) strongly agree scale was used to measure the attitudes towards YouTube ads, see table (1). Chronbach's alpha for this measure was (0.748). 


\section{4) Intentions to watch YouTube advertising}

To measure respondents' intentions to watch YouTube advertising, the researcher used one item "I intend to watch YouTube advertising" with a 5-point Likert scale ranging from (0) Never to (4) Always.

\section{5) The effects of exposure to YouTube advertising}

These effects were measured by twelve items (four items to measure cognitive effects, three to measure affective or emotional effects, and five items to measure behavioral ones), subjects responded to each item with a 5-Point Likert scale ranging from (0) strongly disagree to (4) strongly agree, Chronbach's alpha for this measure was (0.908).

\section{RESEARCH FINDINGS}

\section{YouTube Usage}

Results indicated that respondents' usage of YouTube is positive but moderately $(\mathrm{M}=2.41, \mathrm{SD}=1.076)$. The results also revealed that the most used YouTube video type among the respondents was drama videos $(\mathrm{N}=218,55.9 \%$ of the sample). This was followed by entertainment $(\mathrm{N}=157,40.3 \%)$; documentary $(\mathrm{N}=88,22.6 \%)$, educational materials $(\mathrm{N}=4,1.2 \%)$; and songs $(\mathrm{N}=3,1 \%)$.

\section{Exposure to YouTube ads}

Results indicated that respondents' exposure to YouTube ads is positive $(\mathrm{M}=3.03, \mathrm{SD}=0.979)$, but the respondents' accidental exposure to YouTube ads $(\mathrm{M}=3.02, \mathrm{SD}=1.157)$ were higher than their selective exposure to these ads $(\mathrm{M}=2.64, \mathrm{SD}=1.158)$. Frequencies results revealed that the most frequent ads were watched by the respondents: Etisalat ad $(\mathrm{N}=182,46.7 \%)$, Social Solidarity ad $(\mathrm{N}=123,31.5 \%)$, DHL ad $(\mathrm{N}=110,28.2 \%)$, Orange ad $(\mathrm{N}=94$, $24.1 \%)$, UNICEF ad $(\mathrm{N}=63,16.1 \%)$, and Samsung ad $(\mathrm{N}=29$, $7.4 \%)$.

\section{Attitudes towards YouTube Advertising}

Results demonstrated that the overall respondents' attitudes towards these ads were also moderate $(\mathrm{M}=1.97, \mathrm{SD}=0.732)$. 
Behavioral Intentions and Cognitive-Affective Effects of Exposure to YouTube Advertisements among College Students

Table 1 The attitudes towards YouTube Advertising

\begin{tabular}{|l|l|ll|}
\hline \multicolumn{1}{|c|}{ SD } & Mean & \multicolumn{1}{c|}{ Attitudes' Items } \\
\hline 1.025 & 2.54 & $1 . \quad$ It is interesting \\
\hline 1.014 & 2.13 & $2 . \quad$ It catches my attention \\
\hline 1.079 & 2.54 & $3 . \quad$ It is one of the best ads \\
\hline .977 & 2.63 & $4 . \quad$ It is a good source of information \\
\hline .995 & 2.34 & $5 . \quad$ it is provide needed information \\
\hline 1.110 & 1.92 & $6 . \quad$ It influences my buying behavior \\
\hline .915 & 2.26 & $7 . \quad$ It is trusted \\
\hline 1.156 & 2.97 & $8 . \quad$ It is intrusive \\
\hline 1.013 & 3.26 & $9 . \quad$ I dislike it \\
\hline 1.125 & 2.87 & $10 . \quad$ It isn't suited to me. \\
\hline
\end{tabular}

\section{Behavioral intentions to watch YouTube advertising}

The results indicated that these intentions were positive but moderately $(\mathrm{M}=2.31, \mathrm{SD}=1.065)$.

\section{Effects of exposure to YouTube advertising}

For the overall sample, the greatest effects of watching YouTube advertising were cognitive ones $(\mathrm{M}=2.18, \mathrm{SD}=1.035)$. This was followed by emotional effects $(\mathrm{M}=1.79, \mathrm{SD}=1.102)$ and behavioral effects of this exposure $(\mathrm{M}=1.72, \mathrm{SD}=0.984)$.

1) Cognitive effects: These effects were measured by four items: These ads provide me information about "product's benefits" $(\mathrm{M}=$ $2.14, \mathrm{SD}=1.158)$, "product's features"( $\mathrm{M}=2.26, \mathrm{SD}=1.157)$, "product's price" $(\mathrm{M}=2.00, \mathrm{SD}=1.243)$, and "product's outlet"(M $=1.93, \mathrm{SD}=1.250)$, Chronbach's alpha for this measure was (0.843).

2) Emotional effects: This measure includes three items: These ads "increase my loyalty to the product" $(\mathrm{M}=1.67, \mathrm{SD}=1.000)$, "increase my loyalty to the product's company" $(\mathrm{M}=1.75, \mathrm{SD}=$ $1.238)$, and "convince me by the product's benefits" $(\mathrm{M}=1.98, \mathrm{SD}$ $=1.000)$, Chronbach's alpha for this measure was (0.847).

3) Behavioral effects: This measure includes five items: Exposure to these YouTube ads help me to: "know how to use products" $(\mathrm{M}=$ $2.33, \mathrm{SD}=1.359)$, "interact directly with the companies or sellers" $(\mathrm{M}=1.62, \mathrm{SD}=1.200)$, "participate in discussions about these ads" $(\mathrm{M}=1.53, \mathrm{SD}=1.262)$, "buy the products" $(\mathrm{M}=1.61, \mathrm{SD}$ 
$=1.251)$, and "advise my friends to buy these products" $(\mathrm{M}=1.48$, $\mathrm{SD}=1.237)$, Chronbach's alpha for this measure was (0.822).

\section{Hypothesized model}

One-way ANOVA indicated that respondents' attitudes toward YouTube ads impact significantly and positively on their behavioral intentions to watch these ads $[\mathrm{F}(4,385)=28.687, \mathrm{p}=.000]$, post-hoc analysis was then carried out using the LSD test to identify significant differences between the groups. LSD post-hoc revealed a significant difference among groups in behavioral intentions to watch YouTube ads. LSD post hoc test revealed that the group of "agree" was the highest compared to all other groups with a significant $p$-value at 0.000 ; it was followed by "strongly agree", "neutral", "disagree" and "strongly disagree". In other words, thus, H1 was supported. For a comparison of differences in behavioral intentions to watch YouTube ads based on attitudes towards these ads, see table (2).

Table 2 LSD Post-hoc comparison of respondents' behavioral intentions to watch YouTube ads based on their attitudes towards these ads.

\begin{tabular}{|c|c|c|c|c|c|}
\hline Sig. & $\begin{array}{c}\text { Mean } \\
\text { difference (I- } \\
\mathbf{J})\end{array}$ & $n$ & $\begin{array}{l}\text { Attitudes toward } \\
\text { YouTube ads }(\mathbf{J})\end{array}$ & $\begin{array}{l}\text { Attitudes toward } \\
\text { YouTube ads (I) }\end{array}$ & Dependent variable \\
\hline $.000 *$ & 1.308 & 10 & Strongly disagree & \multirow[t]{3}{*}{ Neutral (238) } & \multirow{4}{*}{$\begin{array}{l}\text { Behavioral intentions } \\
\text { to watch YouTube ads. }\end{array}$} \\
\hline $.000 *$ & .935 & 72 & Disagree & & \\
\hline $.000 *$ & -.625 & 61 & Agree & & \\
\hline $.000 *$ & 1.306 & 72 & Disagree & Strongly Agree (9) & \\
\hline
\end{tabular}

One-way ANOVA also indicated that there was a significant impact for respondents' behavioral intentions to watch YouTube ads on their exposure to these ads $[\mathrm{F}(4,385)=22.282, p=.000]$. LSD post-hoc comparison indicated that a significant difference among groups in the amount of time spent watching the YouTube ads can be attributed exclusively to the group of "always" that was the highest compared to all other groups with the significant p-value at 0.01 ; it was followed by "often", "sometimes", "rarely", and "never", therefore, H2 was supported. For a comparison of differences in behavioral intentions to watch YouTube ads, see table (3). 
Behavioral Intentions and Cognitive-Affective Effects of Exposure to YouTube Advertisements among College Students

Table 3 LSD Post-hoc comparison of respondents' exposure to YouTube ads based on their behavioral intentions to watch these ads.

\begin{tabular}{|l|l|l|l|l|l|}
\hline Sig. & $\begin{array}{c}\text { Mean } \\
\text { difference (I- } \\
\mathbf{J})\end{array}$ & $\boldsymbol{n}$ & $\begin{array}{c}\text { Behavioral intentions } \\
\text { to watch YouTube } \\
\text { ads(J) }\end{array}$ & $\begin{array}{c}\text { Behavioral intentions } \\
\text { to watch YouTube } \\
\text { ads (I) }\end{array}$ & $\begin{array}{c}\text { Dependent } \\
\text { variable }\end{array}$ \\
\hline $.003 *$ & -.667 & 71 & Rarely & Never (21) & $\begin{array}{l}\text { Exposure to } \\
\text { YouTube ads }\end{array}$ \\
\cline { 1 - 2 } $.000 *$ & -.848 & 110 & Sometimes & \\
\cline { 1 - 2 } $.000 *$ & -1.411 & 143 & Often & & \\
\hline $.000 *$ & -1.670 & 45 & Always & & \\
\hline
\end{tabular}

To test the effect of respondents' exposure to YouTube ads on a) cognitive, b) affective, and c) behavioral effects of this exposure, three separate One-way ANOVA tests were run. The results indicated that there was significant effects for respondents' exposure to YouTube ads on cognitive $[\mathrm{F}(4,385)=5.435, p=.000]$, affective $[\mathrm{F}(4,385)=$ $5.405, p=.000]$, and behavioral $[\mathrm{F}(4,385)=13.030, p=.000]$ effects of this exposure as shown in table (4).

Table 4 ANOVA results for the impact of YouTube ads exposure on the effects of this exposure.

\begin{tabular}{|c|l|l|l|l|}
\hline \multicolumn{4}{|c|}{ Exposure to YouTube ads } & \multirow{2}{*}{ Items } \\
\hline $\boldsymbol{p}$ & $\boldsymbol{F}$ & $\boldsymbol{d} \boldsymbol{f}_{\text {within }}$ & $\boldsymbol{d} \boldsymbol{f}_{\text {between }}$ & \\
\hline $.000^{*}$ & 5.435 & 385 & 4 & Cognitive effects \\
\hline $.000^{*}$ & 5.405 & 385 & 4 & Affective effects \\
\hline $.000^{*}$ & 13.030 & 385 & 4 & Behavioral effects \\
\hline
\end{tabular}

LSD Post-hoc tests revealed a significant difference among groups in cognitive, affective, and behavioral effects of exposure to YouTube ads. post hoc test indicated that the group of "respondents who often watch YouTube ads" was the highest compared to all other groups with the significant $p$-value at 0.01 ; it was followed by "sometimes", "always", "rarely", and "never". Therefore, H3, H4, and H5 were supported. For a comparison of differences in these effects based on the exposure to these ads, see table (5). 
Table 5 LSD Post-hoc comparison of cognitive, affective, and behavioral effects of exposure to YouTube ads based on this exposure.

\begin{tabular}{|c|c|c|c|c|c|}
\hline Sig. & $\begin{array}{c}\text { Mean } \\
\text { difference (I-J) }\end{array}$ & $n$ & $\begin{array}{c}\text { Exposure to } \\
\text { YouTube ads }(J)\end{array}$ & $\begin{array}{c}\text { Exposure to } \\
\text { YouTube ads (I) }\end{array}$ & $\begin{array}{l}\text { Dependent } \\
\text { variable }\end{array}$ \\
\hline $.001 *$ & -1.213 & 75 & Sometimes & \multirow[t]{3}{*}{ Never (9) } & \multirow[t]{4}{*}{ Cognitive effects } \\
\hline $.000 *$ & -1.295 & 132 & Often & & \\
\hline $.001 *$ & -1.209 & 153 & Always & & \\
\hline $.011 *$ & -.642 & 75 & Sometimes & Rarely (21) & \\
\hline $.005^{*}$ & -1.080 & 75 & Sometimes & \multirow[t]{3}{*}{ Never (9) } & \multirow{4}{*}{$\begin{array}{l}\text { Affective or } \\
\text { emotional effects }\end{array}$} \\
\hline $.003 *$ & -1.129 & 132 & Often & & \\
\hline $.000 *$ & -1.301 & 153 & Always & & \\
\hline $.024 *$ & -.604 & 75 & Sometimes & Rarely (21) & \\
\hline $.000 *$ & 1.346 & 9 & Never & \multirow[t]{4}{*}{ Always (153) } & \multirow[t]{4}{*}{ Behavioral effects } \\
\hline $.000 *$ & 1.108 & 21 & Rarely & & \\
\hline $.000 *$ & .613 & 75 & Sometimes & & \\
\hline $.021 *$ & .255 & 132 & Often & & \\
\hline
\end{tabular}

Pearson's correlation indicated that there was a positive relationship between cognitive and affective effects of YouTube ads exposure $(\mathrm{r}=.603, p=.000)$, there was a positive relationship between cognitive and behavioral effects of this exposure $(r=.498$, $\mathrm{p}=.000)$, and there was a significant relationship between effective and behavioral effects of this exposure too $(\mathrm{r}=.586, \mathrm{p}=.000)$, therefore, H6, H7, H8 were supported, see table (8). 
Table 6 Person correlation results for relationships among cognitive, affective and behavioral effects of exposure to these ads

\begin{tabular}{|l|l|l|l|l|l|l|}
\hline \multicolumn{2}{|l|}{ Behavioral effects } & \multicolumn{2}{l|}{ Affective effects } & \multicolumn{2}{l|}{ Cognitive effects } & \multirow{2}{*}{ Variables } \\
\hline$p$ & $r$ & $p$ & $r$ & $p$ & $r$ & \\
\hline $.000^{*}$ & .498 & $.000^{*}$ & .603 & - & 1 & Cognitive effects \\
\hline $.000^{*}$ & .586 & - & 1 & $.000^{*}$ & .603 & Affective effects \\
\hline- & 1 & $.000^{*}$ & .586 & $.000^{*}$ & .498 & Behavioral effects \\
\hline
\end{tabular}

Based on the results of the hypotheses tests, the following model was proposed, see figure (2).

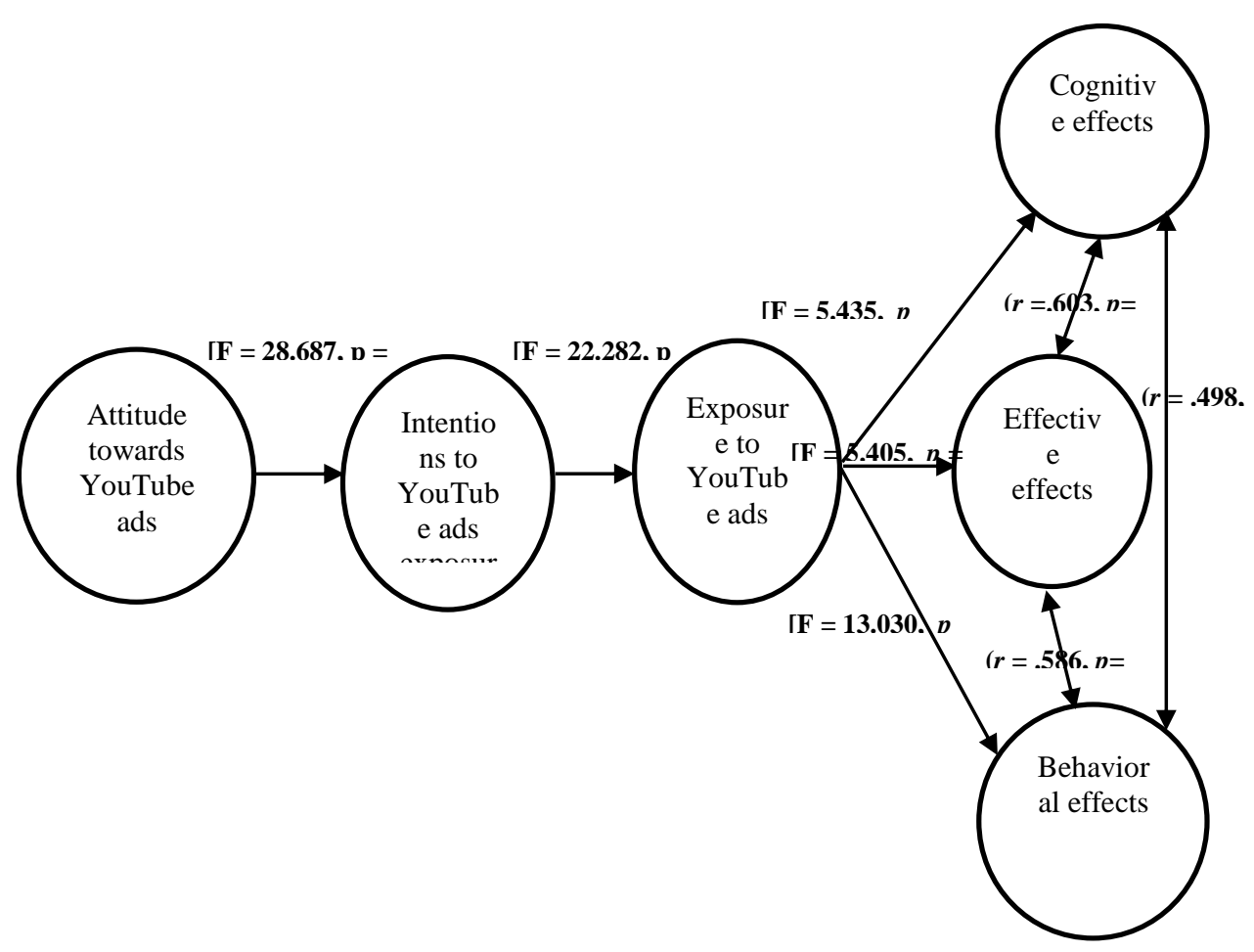

Figure 2: Proposed research model 
Behavioral Intentions and Cognitive-Affective Effects of Exposure to YouTube Advertisements among College Students

\section{DISCUSSION AND CONCLUSION}

The results show four interesting patterns about the relation among attitude towards YouTube ads, behavioral intentions to these ads, exposure to YouTube ads and the effects of these ads. The current study reveals that respondents' attitudes toward YouTube ads have a significant and positive effect on their behavioral intentions to watch these ads. This result reinforces some previous research (e.g. Lee, Ham \& Kim, 2013; Lee \& Lee, 2011; Nainggolan, Azzahro \& Handayani, 2018; Sanne \& Wiese, 2018) that revealed that attitudes toward watching online video ads positively relate to the intention to watch these ads.

Another interesting result is that respondents' behavioral intentions to watch YouTube advertising significantly affect their actual engagement with this advertising. This result is consistent with $\mathrm{Wu}$, Lin and Lin (2011) result that indicated that users' intentions to search ads keywords were positively associated with their searching behaviors, and it also agrees with Sanne \& Wiese (2018) result that stated that the intentions to watch Facebook advertising significantly influence on engagement with Facebook advertising.

The third important finding of this study is that respondents' engagement with YouTube advertising has a significant and positive impact on its cognitive, affective and behavioral responses. This result is different from Hong (2014) that found that online ads have some negative cognitive, affective and behavioral effects, and it reinforces Martín-Santana and Beerli-Palacio (2012) study that disclosed that exposure to online ads relate significantly and positively with cognitive, affective and behavioral effects of advertising, and it also agree with Zenetti, Bijmolt, Leeflang, and Klapper (2014) also found that exposure to search engine advertising has a positive effect on both advertising awareness (cognitive effect) and brand consumption (behavioral effect).

The fourth important result of this study is that the cognitive, affective and behavioral effects of YouTube ads are positively associated with each other. Hamidizadeh, Yazdani, Tabriz, and Latifi (2012) indicated that cognitive response doesn't have a significant effect on the behavioral response. This result reinforces some previous 
research (e.g., Ahn \& Back, 2017; Agapito, Valle \& Mendes, 2013; Back \& Parks, 2003; Hinson, Boateng, Renner \& Kosiba, 2019; Matthes \& Beyer, 2015; Punyatoya, 2019) that demonstrated the positive relationships among cognitive, affective and behavioral effects.

This study sheds light on the importance of YouTube as an advertising medium, the attitudes toward these ads, intentions to watch them, engagement with these ads and their perceived effects. It also addresses advertisers to exploit YouTube to promote their products effectively. But it has some limitations: First, it did not analyze the content of Egyptian YouTube ads to identify their characteristics. Second, the purposive sampling method limits the study's generalize ability. 


\section{REFERENCES}

Ahn, J., \& Back, K.-J. (2017). Influence of brand relationship on customer attitude toward integrated resort brands: A cognitive, affective, and conative perspective. Journal of Travel \& Tourism Marketing, 35(4), 449-460.

Agapito, D., Oom do Valle, P., \& da Costa Mendes, J. (2013). The cognitive-affectiveconative model of destination image: A confirmatory analysis. Journal of Travel \& Tourism Marketing, 30(5), 471-481.

Ajzen, I. (1991). The theory of planned behavior. Organizational Behavior and Human Decision Processes, 50(2), 179-211.

Arantes, M., Figueiredo, F., \& Almeida, J. M. (2018). Towards understanding the consumption of video-ads on YouTube. The Journal of Web Science, 4(1), 1-19.

Arantes, M., Figueiredo, F., Almeida, J. M., \& Prates, R. O. (2018, October). An investigation of user actions and experiences when exposed to YouTube video ads. In Proceedings of the 24th Brazilian Symposium on Multimedia and the Web (pp. 283-290). ACM.

Araújo, C. S., Magno, G., Meira, W., Almeida, V., Hartung, P., \& Doneda, D. (2017, September). Characterizing videos, audience, and advertising on Youtube channels for kids. International Conference on Social Informatics (pp. 341-359). Springer, Cham.

Asghar, W., Abbasi, M. N., \& Zafarullah, M. (2015). Impact of advertisement and sales promotion on consumer cognitive buying behavior: A study of low involvement (FMCG) products. Pakistan Journal of Social Sciences (PJSS), 35(2), 585-598

Ball-Rokeach, S. J., \& DeFleur, M. L. (1976). A dependency model of mass-media effects. Communication Research, 3(1), 3-21.

Back, K. J., \& Parks, S. C. (2003). A brand loyalty model involving cognitive, affective, and conative brand loyalty and customer satisfaction. Journal of Hospitality \& Tourism Research, 27(4), 419-435.

Dehghani, M., Niaki, M. K., Ramezani, I., \& Sali, R. (2016). Evaluating the influence of YouTube advertising for the attraction of young customers. Computers in human behavior, 59, 165-172.

Duffett, R. G. (2017). Influence of social media marketing communications on young consumers' attitudes. Young Consumers, 18(1), 19-39.

Fishbein, Martin and Icek Ajzen (1975). Belief, attitude, intention, and behavior: An introduction to theory and research, reading, MA: Addison-Wesley Publishing Company.

Hamidizadeh, M. R., Yazdani, N., Tabriz, A. A., \& Latifi, M. M. (2012). Designing and validating a systematic model of e-advertising. International Journal of Marketing Studies, 4(2),130-149.

Hinson, R., Boateng, H., Renner, A., \& Kosiba, J. P. B. (2019). Antecedents and consequences of customer engagement on Facebook. Journal of Research in Interactive Marketing. 13 (2), 204-226.

Hong, Y. H. (2014). Which one is more annoying? Comparing the cognitive, affective and conative effects of button ads and pop-up Ads. Journal of Business and Economics, 5(11), 2074-2084. 
Izquierdo-Yusta, A., Olarte-Pascual, C., \& Reinares-Lara, E. (2015). Attitudes toward mobile advertising among users versus non-users of the mobile Internet. Telematics and Informatics, 32(2), 355-366.

Koshy, L., \& Manohar, S. (2018). Exploring the intention to watch advertisements on YouTube among Youth. SSRN Electronic Journal. DOI:10.2139/ssrn.3271497

Kuo, Y.-F., \& Yen, S.-N. (2009). Towards an understanding of the behavioral intention to use $3 \mathrm{G}$ mobile value-added services. Computers in Human Behavior, 25(1), 103-110.

Lavidge, R. J., \& Steiner, G. A. (1961). A model for predictive measurements of advertising effectiveness. Journal of Marketing, 25(6), 59-62.

Lee, J., \& Lee, M. (2011).Factors influencing the intention to watch online video advertising. Cyberpsychology, Behavior, and Social Networking, 14(10), 619-624.

Lee, J., Ham, C. D., \& Kim, M. (2013). Why people pass along online video advertising: From the perspectives of the interpersonal communication motives scale and the theory of reasoned action. Journal of Interactive Advertising, 13(1), 1-13.

Li, H., \& Leckenby, J. D. (2004). Internet advertising formats and effectiveness. An invited chapter for Thorson \& Schumann. Retrieved 20 September from http://www.ciadvertising.org/studies/reports/measurement/ad_format_print.pdf.

Luarn, P., \& Lin, H.-H. (2005). Toward an understanding of the behavioral intention to use mobile banking. Computers in Human Behavior, 21(6), 873-891.

Martínez-Ruiz, M. P., Izquierdo-Yusta, A., Olarte-Pascual, C., \& Reinares-Lara, E. (2018.). Do affective variables make a difference in consumers' behavior toward mobile advertising?. Frontiers in Psychology, 7, 2018.

Martín-Santana, J. D., \& Beerli-Palacio, A. (2012). The effectiveness of web ads: rectangle vs contextual banners. Online Information Review, 36(3), 420-441.

Matthes, J., \& Beyer, A. (2015). Toward a cognitive-affective process model of hostile media perceptions: A multi-country structural equation modeling approach. Communication Research, 44(8), 1075-1098.

Moriarty, S., Mitchell, N. D. \& Wells, W. D. (2012). Advertising \&IMC: Principles and Practice, 9th Edition. Boston: Pearson.

Nainggolan, C., Azzahro, F., \& Handayani, P. W. (2018). Factors Affecting Users' Purchase Intention and Attitudes towards Mobile Advertising. Proceeding of the Electrical Engineering Computer Science and Informatics, 5(5), 11-16.

O'Toole, G. (2011). Social impact of digital media and advertising: a look at consumer control. In Handbook of Research on Digital Media and Advertising: User Generated Content Consumption (pp. 180-193). IGI Global.

Punyatoya, P. (2019). Effects of cognitive and affective trust in online customer behavior. Marketing Intelligence \& Planning, 37(1), 80-96.

Rashid, Y., \& Zeeshan, M. (2018). Customer Attitude towards Online Ads of Smartphone Brands: A Netnographic Analysis of User-Generated Comments on YouTube. Journal of Management Sciences, 5(2), 40-64.

Rubin, A. M., \& Windahl, S. (1986). The uses and dependency model of mass communication. Critical Studies in Mass Communication, 3(2), 184-199. 
Sanne, P. N., \& Wiese, M. (2018). The theory of planned behavior and user engagement applied to Facebook advertising. South African. Journal of Information Management, 20(1), 1-10.

Schivinski, B. \& Dabrowski, D. (2015). The impact of brand communication on brand equity through Facebook, Journal of Research in Interactive Marketing, 9 (1), 31-53.

Shimp, T. A., \& Andrews, J. C. (2013). Advertising, promotion, and other aspects of integrated marketing communications. 9th edition. Mason, OH: Southwestern Publishing.

Smith, L. R., \& Smith, K. D. (2011). What a difference a download makes: Political advertising in the digital age. In Handbook of Research on Digital Media and Advertising: User Generated Content Consumption (pp. 577-603). IGI Global.

Tarkiainen, A., \& Sundqvist, S. (2005). Subjective norms, attitudes, and intentions of Finnish consumers in buying organic food. British Food Journal, 107(11), 808-822.

Thorson, E., \& Duffy, M. (2012). Advertising age: The principles of advertising and marketing communication at work. Nelson Education.

Trafimow, D., \& Finlay, K. A. (1996). The importance of subjective norms for a minority of people: Between-subjects and within-subjects analyses. Personality and Social Psychology Bulletin, 22(8), 820-828.

Trumbo, C. W. (2015). The effect of electronic cigarette advertising on intended use among college students. Addictive Behaviors, 46, 77-81.

Vakratsas, D., \& Ambler, T. (1999). How advertising works: what do we know?. Journal of Marketing, 63(1), 26-43.

Voorveld, H. A., van Noort, G., Muntinga, D. G., \& Bronner, F. (2018). Engagement with social media and social media advertising: The differentiating role of platform type. Journal of Advertising, 47(1), 38-54.

Wu, S., Lin, C. S., \& Lin, J. (2011). An empirical investigation of online users' keyword ads searches behaviors. Online Information Review, 35(2), 177-193.

Yang, K.-C., Huang, C.-H., Yang, C., \& Yang, S. Y. (2017). Consumer attitudes toward online video advertisement: YouTube as a platform. Kybernetes, 46(5), 840-853.

Zenetti, G., Bijmolt, T. H. A., Leeflang, P. S. H., \& Klapper, D. (2014). Search engine advertising effectiveness in a multimedia campaign. International Journal of Electronic Commerce, 18(3), 7-38.

\section{CONTRIBUTOR DETAILS}

Dr. Abd El-Basit Ahmed Hashem Mahmoud (Ph.D., University of TU Ilmenau, Germany) is an Associate Professor in Mass Communication College, Zarqa University, Jordan, and Associate Professor in the Department of Mass Communication, Faculty of Arts, Sohag University, Egypt. He is the former head of the Public Relations and Advertising Department, Mass Communication College, Yarmouk University, Jordan. His research interests are in the areas of advertising, online communication, cross-cultural marketing, and discourse analysis. He has several publications in both English and Arabic.

Contact: Mass Communication College, Zarqa University, Jordan

P. O. Box: 13132, Jordan.

E-mail: abmahmoud@zu.edu.jo/abdelbasit_shaheen@yahoo.com 
Behavioral Intentions and Cognitive-Affective Effects of Exposure to YouTube Advertisements among College Students

Dr. Othman Fekry Abdelbaki (Ph.D., Cairo University, Egypt) is an assistant professor in the faculty of Mass Communication, Cairo University, Egypt. His research interests are in the areas of Journalism, press editing, online communication, communication theory, and discourse analysis. He has several publications.

E-mail: osman.fekry@ hotmail.com 